\title{
Eurodollars and the U.S. Money Supply
}

\author{
ANATOL B. BALBACH and DAVID H. RESLER
}

\section{INPRODUCTION}

T $\mathrm{T}$ is frequently asserted that the Eurodollar market has contributed substantially to worldwide inflation and general economic instability. Eurodollars allegedly move with ease from country to country, disrupting national credit and money markets and creating fears about the inflationary consequences for the U.S. economy if all these "dollars" pour back into the U.S. banking system.

Inflation results when spending grows faster than real output. If excess spending occurs because the quantity of money grows faster than people's desire to hold money, then Eurodollar transactions can increase inflation only if they reduce the growth of output, reduce people's desire to hold money, or increase the amount of money in existence. There is no theoretical or empirical evidence that Eurodollar transactions have reduced output growth. The extent to which the Eurodollar market has reduced the demand for domestic currencies remains uncertain. Consequently, if the Eurodollar market contributes to inflation, it does so either by increasing the amount of money in existence or impeding control of domestic money stocks. The extent to which the Eurodollar market has independently contributed to an expansion of the world money supply has been the focus of a num. ber of studies. ${ }^{1}$ Despite this research effort, serious questions remain about whether or not the volume of Eurodollar balances should be included in any aggregation of the world money stock.

This article, however, addresses a different but related question by focusing on the relationship between the Eurodollar market and monetary control. It assumes throughout that the Federal Reserve System does not engage in Eurodollar transactions or alter its monetary policy as a result of such transactions. The first section of the article describes the Eurodollar market. The second section illustrates, through the use of balance sheets, how Eurodollar transactions may affect the U.S. money supply. The third section investigates the effects of Eurodollar transactions on the U.S. money supply in the context of a money multiplier model.

1 For representative studies on this question that make use of a multiplier framework, see John H. Makin, "Identifying a Reserve Base for the Eurodollar System," Journal of Finance (June 1973), pp. 609-17; and Boyden E. Lee, "The Eurodollar Multiplier," Joumat of Finance (September 1973), pp. 86774. For an alternative portfolio balance approach that chal lenges the relevance of the multiplier framework as applied to the Eurodollar market, see Joln Hewson and Eisuke Sakakibara, The Eurocurrency Markets and their Implications (Lexington, Mass.: Lexington Books, 1975). 


\section{A Brief Descriptive History of the Eturodollar Market}

A Eurocurrency market consists of banks that accept deposits and make loans in currencies other than those of their own country. ${ }^{2}$ The modern Eurodollar market evolved from the special circumstances of the post-World War II international finance system. ${ }^{3}$ Early in this period, many foreigners found it convenient to deposit dollar balances with banks in Europe. As in the post-World War I period, these funds were generally repatriated to the U.S. as European banks acquired dollar assets directly through the U.S. money market.4 By the end of the $1950 \mathrm{~s}$, however, Eurobanks began lending dollar-denominated funds, and this activity spawned the modern Eurodollar market.

The primary reason for this market's development and subsequent expansion is that, like other financial market innovations, it reduces the costs of international trade by offering traders an efficient means of economizing on transaction balances in a world where most trade is denominated and transacted in dollars. Regulation $Q$ ceilings and differential reserve requirements for various categories of U.S. bank liabilities also contribute to further Eurodollar intermediation. U.S. banks periodically encounter difficulty in attracting and retaining corporate deposit balances because of effective Regulation $Q$ interest rate ceilings. ${ }^{5}$ Foreign branches of U.S. banks, however, do not face these restrictions. Consequently, as interest rates rise and the yield differential between Eurodollar and domestic deposits widens, corporate depositors channel funds into Eurodollar accounts. Foreign branches of U.S. banks then can re-lend the funds back to the parent institution. In this way, many U.S. banks are able to mitigate some of the consequences of the disintermediation that accompanies periods of

${ }^{2}$ Although U.S. banks are prohibited from accepting deposits or making loans in currencies other than U.S. dollazs, banks in other countries, including foreign branches of U.S. banks, are not.

3 For a detailed discussion of the history of this market see Paul Einzig, The Eturodollar System, 5th ed. (New York: St. Martin's Press, 1973).

4 Some anthors have attributed a special role in the development of the Eurodollar market to Communist bloc countries. It is argued that these countries feared that their assets would be frozen by the U.S. govermment as part of Cold War political strategy.

"The emergence of the large denomination certificate of deposit (CD) market can be traced to the early $1960 \mathrm{~s}$, when corporate financial officers began managing cash positions more carefully to take advantage of the higher interest rates offered on short-term time deposits. (Banks have not been permitted to pay explicit interest on demand deposits.) rising U.S. interest rates. ${ }^{6}$ Finally, differences in reserve requirements across bank liabilities often reinforce U.S. banks' incentive to secure funds from Eurodollar sources.

\section{The Eurodollar Banking System}

Because Eurobanks intermediate between lenders and borrowers, the Eurodollar market, like any other fractional reserve banking system, can expand the amount of Eurodollar liabilities. Since not all depositors will withdraw their funds simultaneously, Eurobanks can lend these deposits, and the transferral of these funds from one bank to another produces a multiple expansion of deposits and credit. In national banking systems, this multiple expansion is limited by the extent to which banks hold required or precautionary reserves. The potential expansion of dollardenominated credit occurring through the Eurodollar system is limited only by the amount of precautionary reserves that Eurobanks hold in order to meet their short-term liquidity needs.

Eurobanks do not issue demand deposits, even though some deposits are of very short duration frequently overnight - and can be transferred from one individual to another easily and conveniently, Despite this rapid transferability, Eurodollars are not generally acceptable as payment for goods and services in any country and therefore are excluded from current definitions of money. ${ }^{7}$ Borrowers of Eurodollars who wish to buy goods and services with the proceeds of a loan must first convert them into some national currency. ${ }^{8}$ Viewed in this light, Eurodollar deposits are similar to savings and time deposits that serve as a "temporary abode of purchasing power,"

In summary, the Eurodollar system can expand credit by some multiple of its reserves, but it cannot create money since its liabilities, unlike those of banks, are not generally acceptable as a means of payment. Although the Eurodollar market does not create money directly, it may generate some important in direct effects if Eurodollar transactions affect domestic money stocks.

Until these borrowings by U.S, banks were subjected to reserve requirements, banks had an additional incentive to acquire such funds.

TThe Federal Reserve Board of Governors does include "overnight Eurodollars held by U.S. residents other than banks at Caribbean branches of member banks" in its current definition of M2. This article, however, focuses on the transactionbased definitions of money - old $\mathrm{Ml}$ and the newly defined $\mathrm{M} 1 \mathrm{~A}$ and $\mathrm{M} \perp \mathrm{B}$.

8This process is analogous to that which occurs when an individual borrows from a savings and loan institution. Before spending these funds, he too ritust first convert the loan into currency or demand deposits at a commercial bank. 


\begin{tabular}{|c|c|c|c|c|c|}
\hline \multicolumn{2}{|c|}{ Public } & \multicolumn{2}{|c|}{ U.S. banks } & \multicolumn{2}{|c|}{ Eurobanks } \\
\hline Assets & Liabilities & Assets & Liabilities & Assets & Liabilities \\
\hline $\begin{array}{l}D D P-\$ 100 \\
E D+\$ 100\end{array}$ & & & $\begin{array}{l}\mathrm{DDE}+\$ 100 \\
\mathrm{DDP}-\$ 100\end{array}$ & $\mathrm{DDE}+\$ 100$ & $E D+\$ 100$ \\
\hline
\end{tabular}

Can Eurodollar Transactions Affect the U.S. Money Stock?

The Eurodollar market and the U.S. monetary system are linked by those transactions in which holders of U.S. dollar-denominated assets deposit dollars in Eurobanks, or in which holders of Eurodollars spend these funds in the United States. The majority of such transactions involves the exchange of short-term assets. For example, an individual or a corporation that owns demand deposits, certificates of deposit, repurchase agreements, Treasury bills, or commercial paper may convert these assets into Eurodollars. Similarly, holders of Eurodollars, or borrowers in the Eurodollar market, may convert these funds into domestic financial instruments or buy goods and services outright.

In the following discussion, four transactions are used to typify the relationship between the Eurodollar and U.S. money markets. ${ }^{9}$ Transactions 1 and 3 involve the conversion of demand deposits into Eurodollars. Transaction 1 assumes that Eurodollar institutions hold their reserve assets in the form of demand deposits at U.S. banks; transaction 3 assumes that these reserve assets are held in the form of balances "due from" U.S. banks. Transactions 2 and 4 involve conversion of other U.S. bank liabilities such as certificates of deposit into Eurodollars. Transactions 2 and 4 maintain the same assumptions as transactions 1 and 3 , respectively, about the form in which Eurodollar institutions maintain their reserves.

For convenience, two additional assumptions are made. First, the Federal Reserve System continues to supply the monetary base at some predetermined constant rate. This assumption is necessary to distinguish the effect of Eurodollar transactions from policyinduced changes in money stock. Second, the required reserve ratio is assumed to be 10 percent on demand deposits and 5 percent on other bank liabilities. 9Athough they do not exhaust all possible asset substitutions,
these four transactions are representative of the way in which Eurodollar-related transactions affect the U.S. money stock.
In transaction 1, a holder of demand deposits at a U.S. bank transfers $\$ 100$ million into Eurodollar deposits at a Eurobank. ${ }^{10}$ On the public's balance sheet, demand deposits (DDP) decline and Eurodollar deposits (ED) rise by the same amount. At the Eurobank, the individual's account is credited and the bank's Eurodollar liabilities rise by $\$ 100$ million. When the check clears, the U.S. bank's demand deposit liability to the public (DDP) declines and the demand deposit liability to the Eurobank (DDE) increases. The Eurobank's balance sheet will record this transaction as an increase in assets.

The impact of this transaction on the U.S. money stock depends on how money is measured. Using the old definition of money (M1), which includes foreign commercial bank demand deposits at U.S, banks, the money supply is unaffected since DDP declined and DDE rose by the same amount. Because DDP and DDE have the same reserve requirements, excess reserves are not affected and no further contraction or expansion of loans and deposits in the U.S. is possible.

On the other hand, if money is measured either by MLA or M1B (which exclude foreign bank demand deposits at U.S. banks), then the money supply decreases by the amount of the transaction since DDP declines while the increase in DDE is not counted. Because excess reserves are still unaffected, there will be no further change in the money stock. Thus, the initial effect of deposit outflows into the Eurodollar market lowers the money stock, as currently measured, by an amount equivalent to the size of the transaction.

It is important to note that in this transaction Eurobanks collectively are assumed to hold total reserves (in the form of demand deposit balances at U.S. banks) equal to the initial dollar outflow from U.S. banks. If, in the extreme, Eurobanks hold no reserves at all, the U.S. money stock, however defined, will be

roThis Eurobank may be a foreign branch of some U.S. bank or an unaffliated foreign bank. 


\section{Transaction 2. Conversion of Certificates of Deposit into Eurodollars}

\begin{tabular}{|c|}
\multicolumn{2}{c}{ Public } \\
Assets \\
\hline CD $\$ 100$ \\
ED $+\$ 100$
\end{tabular}

unaffected. ${ }^{11}$ However, to the extent that Eurobanks hold some precautionary reserves in the form of demand deposits at U.S. banks, the qualitative effect of the Eurodollar transactions is the same as outlined above.

In transaction 2, the owner of a certificate of deposit (CD) at a U.S. bank fails to renew a maturing CD and deposits the funds as a Eurodollar deposit at some foreign bank. On the public's balance sheet, CDs fall and Eurodollar deposits rise. At the Eurobank, Eurodollar liabilities increase and, when the transaction clears, the foreign bank's deposits at the U.S. bank rise. At the U.S. bank, domestic CDs fall while liabilities to foreign banks rise. If money is measured as M1, then the increase in DDE implies an immediate increase in the money supply. On the other hand, if M1B (or MlA) is used, the money stock does not change since neither CDs nor DDEs are included in the definition of money. In both cases, however, bank excess reserves decline. Because the DDE reserve requirement is 10 percent and the $C D$ reserve requirement is 5 percent, an increase in DDE, offset by an equivalent decrease in CDs, raises banks' required reserves by 5 percent of the transaction. Since banks must contract loans and deposits, the money stock will decline. Thus, in the case of Ml, the net effect is an expansion (an immediate increase in M1 plus a subsequent, less than fully offsetting, contraction caused by a decrease in excess reserves). In the case of MIB, there is a net contraction (no immediate change in $\mathrm{M} 1 \mathrm{~B}$ - only the subsequent contraction).

These results are derived from the assumption that the Eurodollar banking system maintains precaution-

11The Eurobank would create a new loan equal to the full amount of DDE, thereby drawing down such balances. The borrower would have to acquire a U.S. demand deposit before he could spend the proceeds of this loan. This transaction then restores the balance sheet of the U.S. bank to its original position. Note that this intermediation through the Eurodollar market generates a greater extension of credit than would have occurred if generated through the U.S. banking system only. ary reserves in the form of demand deposit balances at U.S. commercial banks. ${ }^{12}$ The effect of Eurodollarrelated transactions on the U.S. money stock will be somewhat different if Eurobanks hold their precautionary reserves in a different form. For instance, the Eurobank receiving the initial deposit transfer from a U.S. bank will, on the day of the transaction, actually receive a credit referred to as balances "due from" the U.S. bank. The U.S. bank initially carries the transaction as balances "due to" a foreign bank. This part of the transaction is analogous to the initial book entries made by domestic banks when funds transferred between them are in the process of collection. Transactions 1 and 2 assume that these "collection balances" are cleared quickly with offsetting changes to U.S. demand deposit balances of the Eurobanks. This assumption is appropriate if the Eurobank wishes to lend to non-bank borrowers.

On the other hand, if the Eurobank continues to carry the "due from" item on its balance sheet, the U.S. bank will record a corresponding liability item "due to" a foreign branch or commercial bank instead of recording a demand deposit. ${ }^{19}$ The Federal Reserve defines the net amount of these "due tos" (gross "due tos," less the U.S. bank's "due froms") as Eurodollar borrowings." In this case, Eurodollar borrowings increase and, because these borrowings are subject to different reserve requirements than demand

12In the event that the Eurodollar banking system held no reserves, the final effect of this second transaction would be to increase the money stock under any definition of money.

13 The Eurobank may consider these funds to be either precautionary reserve balances or an earning asset like any other loan, depending on the nature of its relationship with the U.S. bank and on whether the "due from" credit explicitly earns interest and is of some specific duration. Whether these funds are regarded as reserves or an eaming asset, their impact on the U.S. money stock is the same as described in the text.

${ }^{14}$ For foreign commercial banks that are not branches of U.S. banks, only those gross "due to" balances not designated as demand deposits are treated as Eurodollar borrowings. For branches of U.S. banks, all gross balances "due to" the branch enter into the calculation of Eurodollar borrowings. 


\section{Transaction 3. Conversion of Demand Deposits into Eurodollars}

\begin{tabular}{l}
\multicolumn{2}{c}{ Public } \\
Assets \\
\hline LDP-\$100 \\
ED $\$ 100$
\end{tabular}

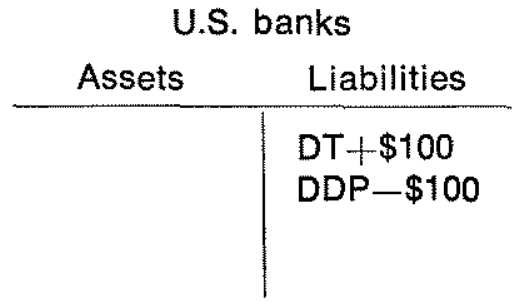

\begin{tabular}{c|c}
\multicolumn{2}{c}{ Eurobanks } \\
Assets & Liabilities \\
\hline$D F+\$ 100$ & ED $+\$ 100$
\end{tabular}

deposits, the money stock is affected differently. The two transactions outlined above are now re-examined under the assumption that the Eurobank chooses to carry an asset in the form of a "due from."

In transaction 3 , as in transaction 1 above, $\$ 100$ milliom in demand deposits at a U.S. bank are converted into Eurodollars. Balance sheet entries in the public's account are identical to those in transaction 1 . Unlike that example, however, the Eurobank records its assets from the transaction as balances "due from" (DF) U.S. banks. At the U.S, bank, DDP declines and funds "due to" (DT) its own branch or other foreign banks rise by $\$ 100$ million. This transfer has two immediate effects. First, M1, M1A, and M1B decline by $\$ 100$ million since DDP falls by $\$ 100$ million and DT is not included in either measure of the money stock. Second, since banks are assumed to hold reserves equal to 10 percent on demand deposits and 5 percent on all other liabilities, including Eurodollar borrowings, the U.S. bank's excess reserves rise by $\$ 5$ million. These excess reserves permit an expansion of loans and deposits, partially offsetting the initial decline in the money supply.

In transaction 4 , the U.S. public converts $\$ 100$ mil- lion in CDs into a Eurodollar deposit at a foreign bank. The change in the public's balance sheet is identical to transaction 2. Eurobank liabilities rise by $\$ 100$ million, as do balances "due from" the U.S. bank. Upon clearing the transaction, U.S. bank liabilities in the form of CDs fall, while funds "due to" its foreign branch rise by $\$ 100$ million. Since neither CDs nor DTs are included in the definitions of money and since both, by assumption, have the same reserve requirement, the money stock is unaffected.

As this discussion illustrates, Eurodollar transactions can affect the U.S. money supply even when the monetary base remains constant. The extent to which Eurodollar transactions affect the money stock depends partially on how money is measured. ${ }^{15}$ Differential reserve requirements combine with Eurodollar Hows to produce an additional effect on the money stock. The transactions outlined here, however, have essentially the same impact on the money stock as do transfers from demand deposits into domestic time deposits or other near-money assets. Consequently, the problems that such transfers might create for monetary control are not unique to Eurodollar transactions,

\section{Transaction 4. Conversion of Certificates of Deposit into Eurodollars Public \\ U.S. banks \\ Eurobanks}

\begin{tabular}{c|c} 
Assets & Liabilities \\
\hline$C D-\$ 100$ \\
$E D+\$ 100$
\end{tabular}

\begin{tabular}{c|c} 
Assets & Liabilities \\
\hline CD $-\$ 100$ \\
DT $+\$ 100$
\end{tabular}

\begin{tabular}{c|c} 
Assets & Liabilities \\
\hline$D F+\$ 100$ & $E D+\$ 100$
\end{tabular}

${ }^{15}$ Additional transactions would have to be examined if the U.S. money supply is measured by broader aggregates, such as M2. For instance, if the demand deposit transfer outlined in transaction 1 were channeled to a Caribbean branch of a U.S. bank, MLA and MIB would decline as before, but $M 2$ would not change. An increase in the magnitude of such transfers might suggest the desirability of redefining trans- action balances. On the other hand, to the extent that such transfers occur because differential reserve requirements encourage banks to raise funds in this way, the differential effects on the various monetary aggregates could be eliminated by uniformly applying reserve requirements to brarch Eurodollar deposits of non-bank institutions. 


\section{EFFECTS OF EURODOLEAR TRANSACTIONS}

Although the foregoing analysis of balance sheets can illustrate the effects of a single transaction, it overlooks other portfolio changes that often accompany the transaction. The transactions described above involved a change in preferences for Eurodollar deposits relative to domestic bank deposits. By holding other asset balances constant, however, these transactions also implicitly altered preferences for all other assets relative to demand deposits (or Eurodollars).

An alternative analytical model provides a more convenient framework for investigating the effect of relative shifts in preferences between only two assets. A money multiplier model can analyze directly the effect on the U.S. money stock of a change in portfolio preferences between any two assets while holding constant the relative preferences for all other assets. The next section develops such a model and provides some quantitative estimates of the impact of Eurodollar transactions on the U.S. money stock.

\section{A Multiplier Model}

The money multiplier framework can be used to analyze how changes in the portfolio decisions of commercial banks and the public affect the domestic money supply. Such changes are typically described by changes in the various ratios that comprise the money multiplier. For instance, a shift in the public's preferences for time deposits relative to demand deposits is characterized by a change in the desired t-ratio, ${ }^{16}$ Money multipliers for three definitions of money - M1, M1A, and M1B - are derived in the appendix and reproduced here.

(1) $\mathrm{m}_{1}=\frac{1+\mathrm{f}+\mathrm{k}}{\Delta}$

(2) $m_{1 \mathrm{a}}=\frac{1+k}{\Delta}$

(3) $\mathrm{m}_{\mathrm{ta}}=\frac{1+\mathrm{k}+\mathrm{n}}{\Delta}$,

where $\Delta=r_{d}[(1+f+d)+n]+r_{t} t+r_{c} c+r_{h} h+$ $\mathrm{e}+\mathrm{k}^{14}$ These multipliers provide the framework for

16When the initial substitution results in a reduction in demand deposits, all other actual ratios will rise momentatily. Because its desired ratios for other assets have not changed, the public will reduce its holdings of other liabilities to restore these ratios to their desired levels. An increase in the t-ratio, for example, will be accompanied by an increase in time deposits and a reduction in demand deposits, currency, etc.

17The denominator $(\Delta)$ of each multiplier includes four different required reserve ratios, in contrast to the simplifying assumption of two reserve requirements made in the preceding section. This approach makes the analysis more realis"
Table 1

\section{Definitions of Ratios Used in the Money Multipliers}

\begin{tabular}{|c|c|}
\hline Ryatio, & $\begin{array}{l}\text { Ratio of the following lems to demand } \\
\text { (the deposits of the nond denank public }\end{array}$ \\
\hline e. & Large denomination certificates of deposit \\
\hline d & Denand deposits of the Us $\mathrm{S}$ Treasury at \\
\hline e & Excess reserves \\
\hline 4 & 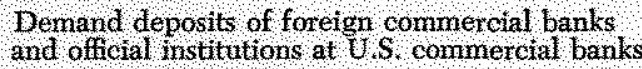 \\
\hline h & Net Eurodollar borrowirgs \\
\hline k & Currency held by the non-bank public \\
\hline $\mathrm{n}$ & $\begin{array}{l}\text { Interest bearng cheokable deposits } \\
\text { (ATS and NOW accounts, and share drafts at } \\
\text { credit lnions) }\end{array}$ \\
\hline$t$ & $\begin{array}{l}\text { The and savings deposit component of the } \\
\text { money stock }\end{array}$ \\
\hline r & Reserve ratios aganst various bank liablities $(1)$ \\
\hline
\end{tabular}

examining the implications of various Eurodollar transactions. For convenience, table 1 defines the ratios that comprise the multipliers.

Eurodollar transactions may affect the multiplier either through domestic banks" net balances "due to" its own branches and to other Eurobanks (i.e., through Eurodollar borrowing) or through foreign commercial banks' deposits with U.S. banks. Shifts in preferences toward Eurodollars similar to those described by transactions 1 and 3 are represented in the multiplier model either by changes in the ratio of foreign commercial bank deposits to domestic demand deposits (the f-ratio) or by changes in the ratio of Eurodollar borrowing to domestic demand deposits (the h-ratio). Asset shifts like those detailed in transactions 2 and 4 entail a shift in preferences from certifcates of deposit to Eurodollars. Thus both the ratio of CDs to domestic demand deposits (the c-ratio) and either the $\mathrm{f}$ - or h-ratio change simultaneously.

Changes in the portfolio decisions of the public and commercial banks affect the money stock. These effects can be analyzed by differentiating these multipliers with respect to changes in the relevant preference ratios. These partial differentials can be translated easily into elasticities.

tic. Nevertheless, the present model retains the assumption that all checkable deposits are subject to a single, uniform reserve requirement. Under current regulations, checkable deposits are subject to different reserve requirements, de pending on bank size and the type of deposit. 
Table 2

Elasticities of Money Multipliers with Respect to Changes in Selected Preference Ratios

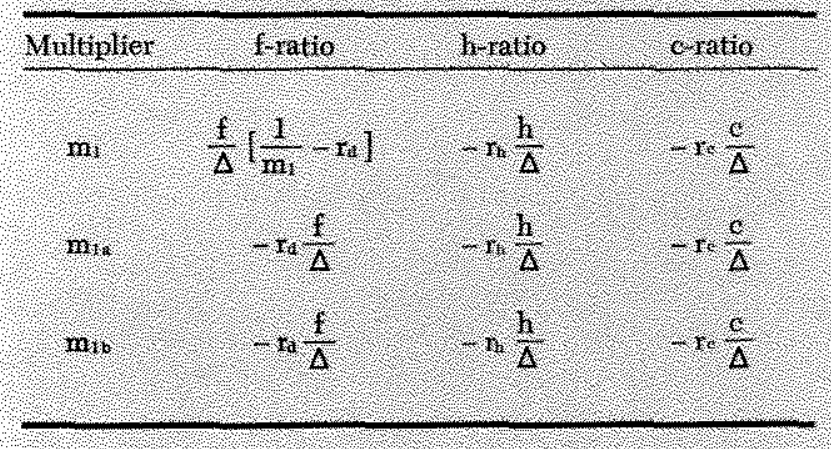

Elasticities were determined for each multiplier with respect to changes in the $f-, h_{-}^{-}$, and c-ratios and are presented in table 2. Because the elasticities for M1A and M1B are identical, only the analysis for $\mathrm{MIB}$ - the broader measure of transactions balances - is discussed below.

In transaction 1, the public's shift from U.S. demand deposits toward Eurodollars was associated initially with an increase in foreign commercial banks' demand deposits at U.S. banks. In the multiplier framework this transaction would be characterized by an increase in the f-ratio. This change assumes that Eurobanks hold precautionary reserve balances in the form of demand deposits at U.S. banks and that these reserves are proportional to the total volume of Eurodollar deposits. ${ }^{18}$ The initial deposit shift toward Eurodollars increases Eurodollar reserves, thereby allowing an expansion of Eurodollar loans and deposits. Although Eurobanks have not changed their desired ratio of Eurodollar reserves as a share of total Eurodollar deposits, Eurodollar reserves as a percent of U.S. demand deposits have risen.

Table 2 indicates that the sign of the elasticity of the MI multiplier $\left(m_{1}\right)$ with respect to changes in the $f$-ratio depends upon the relationship between $m_{1}$ and the average reserve ratio against demand deposits $\left(r_{d}\right)$. Over the past two decades, $m_{1}$ has rarely fallen below 2.5, and the highest marginal reserve requirement has never exceeded .17. Clearly then, for even these extreme values of $r_{i}$ and $m_{1}$, the elasticity of

\footnotetext{
18This simplifying assumption probably overstates the extent to which such deposits serve as reserves for the Eurodollar system and consequently overstates the effect that Eurom dollars have on the U.S. money stock.
}

$m_{I}$ with respect to the f-ratio is positive. That is, an increase in $\mathrm{f}$ is associated with an increase in the U.S. money stock as measured by $\mathrm{Ml}$. In contrast, the elasticity of the M1B multiplier $\left(\mathrm{m}_{1 \mathrm{~B}}\right)$ with respect to changes in the $\mathrm{f}$-ratio is negative. The difference between the $m_{1}$ and $m_{1 b}$ elasticities results from excluding foreign commercial bank deposits from the new measures of the U.S. money stock. Further, for plausible values of $m_{1}$ and $r_{d}$, the absolute value of the elasticity of $m_{ \pm}$with respect to $f$ exceeds that of $\mathrm{m}_{1 \mathrm{~b}}$.

Changes in the h-ratio reflect a preferential shift in the composition of U.S. bank liabilities toward Eurodollar borrowing. As shown in table 2, elasticities for each multiplier with respect to the ratio of Eurodollar borrowing to domestic demand deposits ( $h$ ) are identical. Thus, changes in Eurodollar borrowing by U.S. banks have a similar effect on the money stock regardless of how money is defined. (Note that if $r_{h}$ is zero, as is currently the case, these elasticities are zero.)

A shift in the preferences of the U.S. non-bank public away from domestically issued CDs is represented by a change in the ratio of CDs to domestic demand deposits (c). If this shift is accompanied by an offsetting change in either the $\mathrm{f}$ - or h-ratio, then the impact on the U.S. money stock will be the result of the combined elasticities of the multipliers with respect to the $c$-and $f$ - (or c-and $h$-) ratios. This is the multiplier counterpart to transactions 2 and 4 above. As shown in table 2, all multipliers have the same negative elasticity with respect to the c-ratio.

Table 3 reports numerical values for these elasticities, calculated from monthly data over the period

\section{Table 3}

\begin{tabular}{|c|c|c|c|}
\hline Mrilliplier & fratio & $1+r a 1101$ & erratio \\
\hline$n_{1}$ & 021 & (-.004 & -0.044 \\
\hline nig & P 006 & ( -004 & -044 \\
\hline$n_{1}$ & 4006 & ४ 004 & -.044 \\
\hline
\end{tabular}

1Bused on the period from 1973 through septenther 1978 . during which Eirodollar borrowings were subject lo reserve regumenents. Tederal Reserve action anounced in 1ugus, 1978 lowered resenve requirenents against such borrowings to zero, begining in October 1978. 
from January 1973 through December $1979.1^{19}$ These elasticities indicate that a $I$ percent increase in the $\mathrm{f}$-ratio would cause a .021 percent increase in $\mathrm{m}_{1}$ and a .006 percent decline in both $\mathrm{m}_{\mathrm{in}}$ and $\mathrm{m}_{\mathrm{il}}$. Further, these calculations reveal that, although the multipliers are more sensitive to fluctuations in the c-ratio, even those elasticities are small. Therefore, unless changes in the ratios are large, they would have little impact on the money stock. For instance, suppose that $m_{1 \mathrm{~h}}$ is 2.5 , that the monetary base is $\$ 160$ billion, and that M1B is $\$ 400$ billion. Holding the base constant, a 1 percent increase in the c-ratio would lower M1B by approximately $\$ 176$ million, while a 1 percent increase in the $f$ ratio would lower M1B by only $\$ 24$ million.

\section{Interest Rate Effects}

Since these ratios are intended to reflect the portfolio behavior of the public and the commercial banking system, they should vary with interest rates. Thus, if the ratios reflecting Eurodollar activity are sufficiently interest-sensitive, changes in interest rates will change the money stock. ${ }^{20}$

The interest-sensitivity of Eurodollar flows depends upon the extent to which Eurodollars are substitutes for domestic deposits. Term Eurodollars are Eurodollar liabilities of a specified maturity, usually 90 days or less. The relative attractiveness of these deposits should vary with their interest rate differential against domestic CDs. If both assets were perfect substitutes, they would require the same yield. On the other hand, if depositors considered domestically issued CDs to be safer or more convenient, Eurodollar deposits would yield a higher interest rate, implying that a positive interest rate spread would prevail even in equilibrium. Any momentary widening of this spread would attract funds to the Eurodollar market. Thus, Eurodollar flows should vary directly with changes in the equilibrium interest rate spread.

The equilibrium spread itself will vary with changes in market interest rates if U.S. bank liabilities are subject to different reserve requirements. For example, as U.S. banks bid competitively for funds, the mar-

${ }^{19}$ The elasticity expressions from table 2 were calculated for each month in the sample and then averaged over the period. For the f-ratio elasticities, a 9 percent average reserve requirement against demand deposits was assumed. For the h- and c-ratios, actual marginal reserve requirements in effect during each month were used.

20The positive (and larger) elasticity of the M1 multiplier, with respect to the f-ratio, suggests that MI would fluctuate more than either M1A or $\mathrm{MlB}$ when the $\mathrm{f}$-ratio changes. If the I-ratio is interest-sensitive, then $M I$ would show greater volatility due to interest rate changes than would either of the new definitions of money. ginal effective cost of funds from various sources tends toward equality. (For convenience, this discussion focuses on only two bank liabilities - U.S. CDs and borrowings from Eurobanks.) Under current regulations, CDs are subject to a higher marginal reserve requirement than are Eurodollar borrowings. ${ }^{21}$ Assuming no reserve requirement against Eurodollar borrowing, the cost of these liabilities to U.S. banks is equalized when the following condition is satisfied:

(4) $i_{n}=\frac{i_{n s} .5}{1-r_{0}}$,

where $i_{\text {D.s. }}, i_{x_{\gamma}}$ and $\mathbf{r}_{\mathrm{c}}$ are, respectively, the domestic CD rate, the Eurodollar interbank lending rate, and the marginal reserve requirement against CDs. ${ }^{22}$

The spread, S, between Eurodollar and U.S. interest rates is defined as:

(5) $\mathrm{S}=\mathrm{i}_{\mathrm{F}}-\mathrm{ivs} \mathrm{s}$,

which upon substitution from equation (4) produces $\left(\frac{r_{c}}{I-r_{c}}\right) i_{\text {U.s. }}$ If U.S. interest rates rise, the spread between Eurodollars and domestic CDs will widen. Differentiating equation (5) with respect to $\dot{i}_{\mathrm{U} . \mathrm{s}}$ yields

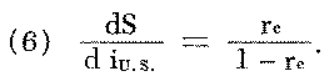

Since $\frac{r_{\varepsilon}}{l-r_{c}}$ is positive, an increase in U.S. market interest rates will be associated with an increase in the Eurodollar/U.S. interest rate differential which, in turn, will stimulate a flow of funds from domestic CDs to the Eurodollar market.

Equation (6) implies that the elasticity of the interest rate spread with respect to the level of U.S. interest rates should be $\left(\frac{\mathrm{r}_{\mathrm{c}}}{1-\mathrm{r}_{\mathrm{c}}}\right) \frac{\mathrm{i}_{\mathrm{v} . \mathrm{s}}}{\mathrm{S}}$. Using the U.S. certificate of deposit rate as the representative U.S. in * terest rate, this elasticity was estimated to be 1.08 over the period from 1973 through $1979 .{ }^{23}$ This value did not differ significantly from unity, indicating that a 1 percent rise in the level of U.S. interest rates is asso-

21Both domestic CDs and net Eurodollar borrowings, as part of a bank's "managed liabilities" were subject to a marginal reserve requirement on the total anount of managed liabilities above some base. This reserve requirement was im posed, in addition to any other reserve requirements, against the liability. At present, this separate reserve requirement is zero against net Eurodollar borrowings and is 6 percent against domestic CDs.

thy there are reserve requirements against Eurodollar borrowing, the equal cast condition becomes $\frac{i_{\theta}}{1-r_{b_{2}}}=\frac{\mathbf{i}_{\mathrm{v}} \mathrm{s}}{1-\mathbf{r}_{\circ}}$.

23 This elasticity was also estimated using the U.S. Treasury bill rate by regressing the logs of the spread against a constant and the logs of the interest rate. Results were similar. 
ciated with a 1 percent increase in the spread. In other words, the spread was some constant fraction of the level of U.S. interest rates.

Over much of this period, reserve requirements against CDs and Eurodollars were identical, implying that any observed spread would correspond to some risk or preference premium on Eurodollar deposits, Thus, the estimated unitary elasticity of this premium, with respect to the level of U.S. interest rates, suggests that the risk premium varies directly with interest rate levels. Interestingly, for the subperiod from September 1978 through December 1979, after reserve requirements against Eurodollar borrowings were lowered to zero, the estimated interest rate spread elasticity of 1.57 differed significantly from unity at the 10 percent confidence level. This result is consistent with the effective risk spread remaining a constant ratio to the level of U.S. interest rates.

If the money multipliers are more interest-sensitive due to Eurodollar activity, the Fed's ability to restrain money and credit expansion could be affected, as some critics of the Eurodollar market have asserted. For example, if Federal Reserve policy temporarily raises domestic interest rates, the volume of CDs could be expected to decline relative to Eurodollar borrowings by U.S. banks. Such Eurodollar-related flows would affect both the c- and hrratios and, consequently, the multipliers. The net impact on the U.S. money stock depends on both the interest elasticities of these ratios and the elasticities of the multipliers with respect to changes in the ratios.

\section{POTENTIAL MMPACT OF ZURODOLLAR WTISACTIONS ON THE U.S. MONEY STOCK}

Two critically important results are evident in the foregoing discussion. First, Eurodollar transactions affect the behavior of the U.S. money supply primarily through their impact on the money multipliers. ${ }^{24} \mathrm{Sec}-$ ond, Eurodollar transactions respond to changes in interest rate differentials that are related to interest rate levels. The behavior of the three relevant ratios is examined to assess the importance of these Eurodollar-related effects for the $1973-79$ period.

Table 4 reports the annual averages (of monthly data) for the $\mathrm{f}-, \mathrm{h}-$, and c-ratios from 1973-79. The

\footnotetext{
24 Even if these Eurodollar transactions have a sizeable impact on the money stock, they would not pose an insumountable barrier to controlling the money stock. To the extent that such effects are predictable, the monetary authority could offset them in its conduct of monetary policy.
}

Table 4

Values of Selected Preference Ratios (Annual Averages of Monthly Data)

\begin{tabular}{|c|c|c|c|}
\hline Year & I ratio & 1-ratio & $\mathrm{Cr}_{\mathrm{ratlo}}$ \\
\hline 1970 & 029 & 038 & 299 \\
\hline 1974 & 037 & 045 & 386 \\
\hline 1075 & 0036 & 026 & 402 \\
\hline 1976 & 038 & .019 & 313 \\
\hline 1977 & 1042 & 600 & 278 \\
\hline 1978 & 043 & 008 & 347 \\
\hline 1979 & 039 & 006 & 359 \\
\hline
\end{tabular}

f-ratio, ranging from .029 to .043 , shows the least amount of year-to-year variation, while the cu and $\mathrm{h}$-ratios are more volatile. Using annual averages of the $\mathrm{c}$ - and h-ratios, however, masks much of their intra-year variability. For instance, despite an apparent increase in 1979 over its 1978 value, the c-ratio actually declined substantially during most of the year and, by year end, was 11 percent lower than it had been at the beginning of the year. The h-ratio, on the other hand, began to rise sharply after Federal Reserve Board action in August 1978 lowered the reserve requirement on net Eurodollar borrowing to zero in August 1978. ${ }^{25}$

Table 5 reports the estimated interest elasticities of these ratios and provides another perspective on their behavior over the past eight years. ${ }^{26}$ All interest elasticities are positive and differ significantly from zero at least at the 10 percent confidence level. The estimated interest elasticities for both the f- and $h$-ratios exceed that of the c-ratio, reinforcing the view that the presence of differential reserve requirements induces more

\footnotetext{
25For a discussion of the extent to which Eurodollar borrowings are substituted for domestic CDs, see David H. Resler, "Does Eurodollar Borrowing Improve the Dollar's Foreign Exchange Value?" this Review (August 1979), pp. 10-16.

26Data reported in table 5 were computed by estimating equations of the general form $\ln x=a_{0}+a_{1} \ln i+u$, where $x$ designates the ratio, $i$ the market yield on three-month Treasury bills, and $\mathrm{u}$ a random ertor term. This equation was estimated by a Cochrane-Orcutt iterative regression tech nique to correct for the presence of serially correlated residuals in the ordinary least squares regression. For the cross elasticities, $\ln c$ was substituted for $\ln i$ in this general expression. Although it would be desirable to estimate the elasticities of these ratios with respect to the interest rate spread, such estimates would require the specification of a full structural model. Consequently, the estimates provided here should be considered to be crude approximations of the interest elasticities that are iseful for a rough determination of the importance of Eurodollar activity in the U.S. money supply process.
} 


\section{Table 5}

\section{Elasticities of Selected Preference Ratios $(1973-79)^{1}$}

\begin{tabular}{|c|c|c|}
\hline Ratio & Interest rates & $0-1 a t o$ \\
\hline$f$ & $196(2017)$ & $=081(-448)$ \\
\hline 1 & $715(1,966)$ & $-441(-649)$ \\
\hline e & $147(2,534)$ & \\
\hline
\end{tabular}

1t-statistics appear in parentheses.

substantial Eurodollar flows during periods of rising interest rates. ${ }^{27}$

Table 5 also reports estimates of the cross elasticities of the $h$ - and $f$-ratios against the c-ratios. Although these elasticities were of the predicted sign, they did not differ significantly from zero, indicating that substitutions between Eurodollar transactions and domestic CDs have not had an important effect on these ratios during the period.

The potential effect of interest-induced Eurodollar transactions on the money stock can be evaluated by using estimates reported in tables 3 and 5. Assuming a constant monetary base of $\$ 160$ billion, the potential effect that Eurodollar transactions would have on M1 and $\mathrm{M} 1 \mathrm{~B}$ was calculated for a 1 percent change in the level of interest rates ( 10 basis points if interest rates are initially 10 percent). ${ }^{28}$ These calculations indicate that if old M1 were used to measure money, the U.S. money stock would be about $\$ 68$ million higher than it would have been otherwise. On the other hand, if measured by M1B, the money stock would have been only about $\$ 44$ million higher. In each case, these changes are less than two one-hundredths of 1 percent of the money stock. Even a 10 percent monthly increase (100 basis points) in domestic interest rates would result in an average monthly money stock

2TElasticity estimates for the h-ratio were derived indirectly. Since calculations of the elasticities were based on logarithmic transformations of the actual ratios and since the h-ratio was regative during some months of the sample period, it was necessary to first transform the $\mathrm{h}$-ratio by adding one to all values for $h$. The estimated elasticity of $1+h$ was then converted into an elasticity for $h$ by multiplying the estimated coefficient of $(1+h)$ by $(1+h) / h$, evaluated at the mean values of $h$ over the sample period.

28 These calculations were based on average values of the multipliers and the estimated elasticities of the three ratios, even though the t-statistics for some coefficients did not differ significantly from zero.
(M1) that would be less than 0.2 of 1 percent higher. Because the assumptions used in this analysis exaggerate the effect that Eurodollar transactions have on the money stock, it is apparent that Eurodollar transactions have only a small effect on the U.S. money supply. Further, the Federal Reserve could easily offset this effect with appropriate open-market transactions.

\section{Summary and Conclusions}

This article has examined the extent to which Eurodollar transactions can affect the U.S. money supply, as measured by current and past Federal Reserve Board versions of narrowly defined money. Using both $\mathrm{T}$-accounts and a money multiplier framework, Eurodollar transactions were shown to affect the U.S. money stock in two ways. First, regardless of the chosen definition of money, Eurodollar flows may affect the U.S. money stock indirectly through their impact on the portfolio composition of U.S. banks' liabilities. Changes in this portfolio composition, whether due to Eurodollar flows or simply domestic asset shifts, may affect the money supply through differential reserve requirements. Second, Eurodollar flows may affect foreign commercial bank demand deposits at U.S. banks. To the extent that these deposits serve as reserves for the Eurodollar system, they will vary directly with flows between the U.S. Eurodollar and the U.S. money markets. Because these deposits are excluded from the new definitions of money, but not from the old M1 definition, Eurodollar flows will affect the various transactions-based definitions differently, Analysis based on the multiplier model indicated that old M1 would be slightly more sensitive to Eurodollar flows than either MIA or M1B.

Since Eurodollar transactions have some impact on narrowly defined money, the question of whether such transactions impair the monetary authorities' control of monetary aggregates merits investigation. The multiplier framework presented in this paper was used to examine systematically Eurodollar-induced effects on the money stock. Based on estimates over the period for 1973-79 - a period of rapid growth in the Eurodollar market - Eurodollar flows were shown to have only minor effects on the U.S. money stock. This evidence warrants the conclusion that the Eurodollar market does not pose a serious threat to the ability of the Federal Reserve to control the money supply. 


\section{APPENDIX: Derivation of Money Multipliers}

\section{A. Definitions of Symbols}

\begin{tabular}{|c|c|c|c|}
\hline Description & Variables & $\begin{array}{l}\text { Ratio } \\
\text { as to } \\
\text { DP }\end{array}$ & $\begin{array}{c}\text { Relevant } \\
\text { reserve } \\
\text { ratios }\end{array}$ \\
\hline \multicolumn{4}{|l|}{ Bank Liabilites } \\
\hline Time Deposits & $\mathrm{T}$ & $t$ & $\mathrm{r}_{\mathrm{t}}$ \\
\hline Demand Deposits & - & - & - \\
\hline Government & $\mathrm{D}_{\mathrm{g}}$ & d & $r_{a_{1}}$ \\
\hline Non-bank public & $\mathrm{D}_{\mathrm{p}}$ & 1 & $r_{i}$ \\
\hline Foreign Commercial bank & $\mathrm{D}_{f}$ & $\mathrm{f}$ & $r_{d}$ \\
\hline Large $\mathrm{CD}$ & CD & $\mathrm{c}$ & Ie \\
\hline Net Eurodollar borrowings & $\mathbf{H}$ & h & $\mathrm{r}_{\mathrm{k}}$ \\
\hline $\begin{array}{l}\text { Interest-bearing checking } \\
\text { deposits }\end{array}$ & ICD & $\mathrm{n}$ & $\mathbf{r}_{\mathfrak{a}}$ \\
\hline NoW accounts & NoW & & \\
\hline Credit union drafts & DCU & & \\
\hline ATS accounts & ATS & & \\
\hline Excess reserves & $\mathbf{E}$ & e & - \\
\hline Currency held by public & $\mathrm{C}$ & k & - \\
\hline Source base & B & - & - \\
\hline Money Stock Measures & $\begin{array}{l}\text { MI } \\
\text { MIA }\end{array}$ & & \\
\hline
\end{tabular}

\section{B. Derivations}

(1) $B=R+C$

(2) $\mathrm{Ml}=\mathrm{m}_{1} \mathrm{~B}=\mathrm{D}_{\mathrm{B}}+\mathrm{D}_{\mathrm{z}}+\mathrm{C}$

$$
\begin{aligned}
\mathrm{MLA} & =\mathrm{m}_{1 \mathrm{a}} \mathrm{B}=\mathrm{D}_{\mathrm{p}}+\mathrm{C} \\
\mathrm{MLB} & =\mathrm{m}_{\mathrm{r}} \mathrm{B}=\mathrm{D}_{\mathrm{p}}+\mathrm{C}+\mathrm{NOW}+\mathrm{DCU}+\mathrm{ATS} \\
& =\mathrm{D}_{\mathrm{p}}+\mathrm{C}+\mathrm{ICD}
\end{aligned}
$$
(3) $\mathrm{T}=\mathrm{t} \mathrm{D}_{\mathrm{p}}$
(4) $\mathrm{D}_{\mathrm{f}}=\mathrm{d} \mathrm{D}_{\mathrm{p}}$
(5) $\mathrm{D}_{\mathrm{z}}=f \mathrm{D}_{\mathrm{p}}$
(6) $\mathrm{CD}=\mathrm{c} \mathrm{D}_{\mathrm{s}}$
(7) $\mathrm{H}=\mathrm{h} \mathrm{D}_{\mathrm{p}}$

$$
\begin{aligned}
& \text { (8) } \mathrm{ICD}=\mathrm{n} \mathrm{D}_{\mathrm{p}} \\
& \text { (9) } \mathrm{E}=\mathrm{e} \mathrm{F}_{\mathrm{p}} \\
& \text { (10) } \mathrm{C}=\mathrm{k} \mathrm{D}_{\mathrm{g}} \\
& \text { (11) } \mathrm{R}=\mathrm{r}_{\mathrm{d}}\left(\mathrm{D}_{\mathrm{p}}+\mathrm{D}_{\mathrm{s}}+\mathrm{D}_{\mathrm{g}}+[\mathrm{ICD}]\right)+\mathrm{r}_{\mathrm{t}} \mathrm{T} \\
& +\mathrm{r}_{\mathrm{s}} \mathrm{CD}+\mathrm{r}_{\mathrm{b}} \mathrm{H}+\mathrm{E}
\end{aligned}
$$

Substituting into equation (11) from equations (3) through (10) produces:

$$
\text { (12) } \begin{aligned}
\mathrm{R} & =\left[\mathrm{r}_{\mathrm{s}}(1+\mathrm{f}+\mathrm{d}+\mathrm{n})+r_{\mathrm{t}} \mathrm{t}\right. \\
& \left.+\mathrm{r}_{\mathrm{c}}+\mathrm{r}_{\mathrm{b}} \mathrm{h}+\mathrm{e}\right] \mathrm{D}_{\mathrm{p}}
\end{aligned}
$$

Thus ( 1 ) can be rewritten as:

$$
\text { (13) } \begin{aligned}
\mathrm{B} & =\left[\mathrm{r}_{\mathrm{d}}(1+\mathrm{f}+\mathrm{d}+\mathrm{n})+\mathrm{r}_{\mathrm{t}} \mathrm{t}\right. \\
& \left.+\mathrm{rcc}_{\mathrm{c}}+\mathrm{r}_{\mathrm{h}} \mathrm{h}+\mathrm{e}+\mathrm{k}\right] \mathrm{D}_{\mathrm{p}}=\Delta \mathrm{D}_{\mathrm{p}}
\end{aligned}
$$

where $\triangle$ equals the bracketed term on the right hand side of $(13)$.

Similarly, the three money definitions can be written as ratios to $\mathrm{D}_{\mathrm{p}}$;

$$
\text { (14) } \begin{aligned}
\mathrm{MI} & =(1+f+k) \mathrm{D}_{\mathrm{p}} \\
\mathrm{MIA} & =(1+\mathrm{k}) \mathrm{D}_{\mathrm{p}} \\
\mathrm{MLB} & =(1+\mathrm{k}+\mathrm{n}) \mathrm{D}_{\mathrm{p}}
\end{aligned}
$$

The three multipliers are derived by dividing all expressions in (14) by (13) producing:

$$
\begin{aligned}
\mathrm{m}_{1} & =\frac{1+\mathrm{f}+\mathrm{k}}{\Delta}, \\
\mathrm{m}_{\mathrm{IR}} & =\frac{1+\mathrm{k}}{\Delta}, \\
\text { and } \mathrm{m}_{\mathrm{th}} & =\frac{1+\mathrm{k}+\mathrm{n}}{\Delta}, \text { as in the text. }
\end{aligned}
$$

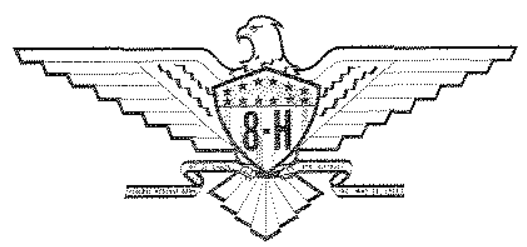

